\title{
Characterization of morphological and meristic traits and their variations between two different populations (wild and cultured) of Cichlasoma festae, a species native to tropical Ecuadorian rivers
}

\author{
Martín A. González ${ }^{1}$, Jorge M. Rodriguez ${ }^{1}$, Elena Angón ${ }^{2}$, Andrés Martínez ${ }^{2}$, Antón Garcia ${ }^{2}$, and \\ Francisco Peña ${ }^{2}$ \\ ${ }^{1}$ Technical State University of Quevedo, Quality Control Department, \\ Av. Quito km 1.5 Vía Santo Domingo de los Tsáchilas, Quevedo, Ecuador \\ ${ }^{2}$ University of Córdoba, Animal Production Department, Ctra. Madrid-Cádiz Km. 396-a, 14071 Córdoba, Spain
}

Correspondence to: Elena Angón (eangon@uco.es)

Received: 7 September 2016 - Revised: 13 October 2016 - Accepted: 18 October 2016 - Published: 31 October 2016

\begin{abstract}
This study was carried out to determine morphometric and meristic characteristics of two populations (wild and cultured) of Cichlasoma festae and to establish whether populations could be discriminated based on morphometric variability. Twenty-two morphometric and four meristic characters were used to test the hypothesis differentiation. Univariate analysis of variance (ANOVA) from 100 adult specimens showed significant differences $(p<0.05)$ for 21 standardized morphometric measurements out of 26 characters among the means of the wild and cultured Cichlasoma festae populations tested. Cross correlation amongst certain morphometric variables (i.e. body weight, total length, standard length, pre-ventral length, AC1, LC1 and P1) were medium-strong $(r \geq 0.5)$, while the remaining were weakly correlated $(r<0.5)$. The length-weight relationship parameter $b$ and condition factor (K) values were respectively 2.21 and 1.97 (indicating allometric growth) for cultured fish groups and 2.86 and $4.07(p<0.05)$ for wild fish groups. The condition factor values were significantly different from each other and showed that feeding of cultured fish should be improved. Both groups were accurately separated ( $>80 \%$ success rate) by linear discriminant functions that included only four morphometric measures.
\end{abstract}

\section{Introduction}

In Ecuador, human communities in coastal as well as inland areas greatly depend on fishery for their incomes and as their source of animal protein (Espinosa-Lemus et al., 2009). Environmental degradation and habitat destruction have caused the decline in the production of fishery resources from the wild, which have diminished greatly (Ajah et al., 2006). Therefore, the domestication of certain fish species is necessary for intensive cultivation in captivity.

The morphometric study of fish is a powerful tool for characterizing strains and/or stocks of the same species which involves the detection of subtle variation in shape, independent of size. These examinations require exact measurements and counts of fin ray elements. For morphological study, morphometric (referring to measurable structures such as fin length, head length, eye diameter, or ratios between such measurements) and meristic (including almost any countable structure, such as fin rays, scales and gill rakers) characters are used. The morphometric characters are classified into genetically (narrow range) controlled, intermediate (moderate range) and environmentally (vast range) controlled characters (Johal et al., 1994). Despite the advent of techniques which directly examine biochemical or molecular genetic variation, the morphometric or meristic methods continue to play an important role in stock identification even today (Swain and Foote, 1999). 
The phenotypic plasticity of fish is very high, with greater variances in morphological traits both within and between populations than any other vertebrates. The cause of variation in the morphometric and meristic characters can be partly attributed to intraspecific variability, which is under the influence of environmental parameters (Wimberger, 1992). Fish are very sensitive to environmental changes and quickly adapt by changing necessary morphometric character (Cabral et al., 2003; Hossain et al., 2010). Morphometric variation between stocks may be applicable for studying short-term environmentally induced variation (Pinheiro et al., 2005). In addition, while both morphometric and meristic characters respond to changes in environmental factors, their responses are different in some situations and can differ from species to species. Finally, is important to farmers to know the differences between cultured and wild fish of different species; this could lead them to understand the chemical, physical, nutritional and sensorial profiles of the wild animal and try to reproduce these in their cultured products (Orban et al., 2003).

In Ecuador, fisheries contribute $7 \%$ to the total supply of animal protein, estimated at $391700 \mathrm{t}$ catches made by capture fisheries in 2011 (FAO, 2011). These catches are made by artisanal fishermen in areas of rivers, lakes, ponds, lagoons, gorges and dams. This activity is performed throughout the year in areas of rivers (Muñoz et al., 2014) or between May and January in other inland areas. Cichlasoma festae, among the freshwater fish (Boulenger, 1899), is a teleost fish (Luna-Figueroa, 2000), native to the continental South America, with a high presence in Ecuador. It is among the nine commercially important species that inhabit the inland waters of Ecuador, Colombia and Peru (Revelo and Elias, 2004). It can be found in rivers, lakes, ponds and dams (Pacheco and Chicaiza, 2008) and noted for its white meat, excellent taste and high acceptance in local cuisine (Barnhill et al., 1974).

In order to produce and preserve this native species, the state administration created the Cachari Experimental Station, located in Babahoyo in the province of Los Ríos, where a conservation programme for native species is currently being developed by the Subsecretaría de Acuacultura of Ministerio de Agricultura, Ganadería, Acuacultura y Pesca (MAGAP). At this experimental station, fingerlings were produced for distribution to farmers and to repopulate the rivers. According to MAGAP, the cultivation of Cichlasoma festae is becoming more and more popular due to its good growth rate, fecundity, ease of manipulation, ability to grow under suboptimal environmental conditions, disease resistance and good consumer acceptance.

Understanding the morphometrics of the fish species will enhance the development of cost-effective aquaculture protocols and thus increase in productivity. Although comparisons of the morphology between cultured and wild fishes from several species have already been carried out by a number of authors (Swain et al., 1991; Ponton and Mérigoux, 2000;
Solem et al., 2006; Solomon et al., 2015), there is a lack of information on the level of this variation for most tropical fish species. Difference among cultured and wild Cichlasoma festae stocks based on morphological characters have not yet been studied and, to the best of our knowledge, this is the first such study that has focused on examining the extent of their morphological variations in cultured and wild environments.

Since this information is vital for the proper management of the fisheries and for optimum utilization of the resources, the aim of the current research was to assess the morphological and meristic traits of Cichlasoma festae caught in different habitats (cultured and wild). This will help in planning further breeding and conservation strategies for this fish and improving productivity.

\section{Material and methods}

\subsection{Data and sampling}

The study included three areas of the Babahoyo River and a fish farm in the province of Los Ríos (Ecuador). The climate of the area is tropical with an average temperature of $25^{\circ} \mathrm{C}$, an annual rainfall of $2400 \mathrm{~mm}$ and a relative humidity of $82 \%$. The salinity of water, both in the river and the fish farm, did not exceed $0.1 \%$; the $\mathrm{pH}$ was between 7.0 and 7.29; the temperature ranged between $19.7^{\circ} \mathrm{C}$ in the river and $24.7^{\circ} \mathrm{C}$ in cultured fish; and dissolved oxygen was between 6.8 and $8.9 \mathrm{mg} \mathrm{L}^{-1}$ in the river and fish farm, respectively. The conductivity values were about $145 \mathrm{mS} \mathrm{cm}^{-1}$.

One hundred matured fish samples (following the rules described by Frost and Kipling, 1980; Chávez-Lomelí et al., 1988; Konings, 1989) of Cichlasoma festae, comprising 50 individuals from natural habitat (wild population) and 50 from a cultured environment (private fish farms, cultured stock), were collected at dawn over the month of May 2016 with the help of standard fishing gears such as cast and hand nets. Since males and females could not be differentiated morphologically, sexing of the sampled fish was not carried out. Specimen collection was performed weekly by purchasing representative samples of the two selected populations from local fishermen (wild fish) or a fish farm (cultured fish). Wild fish were caught from three different locations within their natural geographic distributions in Babahoyo River (Los Ríos province, Ecuador). Cultured fish were collected from the fish farm. Directly after catching, the fish were placed at the same time in a mixture of $40 \mathrm{~L}$ of ice and $40 \mathrm{~L}$ of water $\left(0.8^{\circ} \mathrm{C}\right)$ until their apparent stunning $(20 \mathrm{~min})$ was over. After confirmation of their death, the fish were identified and weighed, and then morphometric measurements and meristic counts were performed.

The study was carried out according to Ecuadorian national recommendations for the management of fish, taking into consideration the rules on animal welfare. 


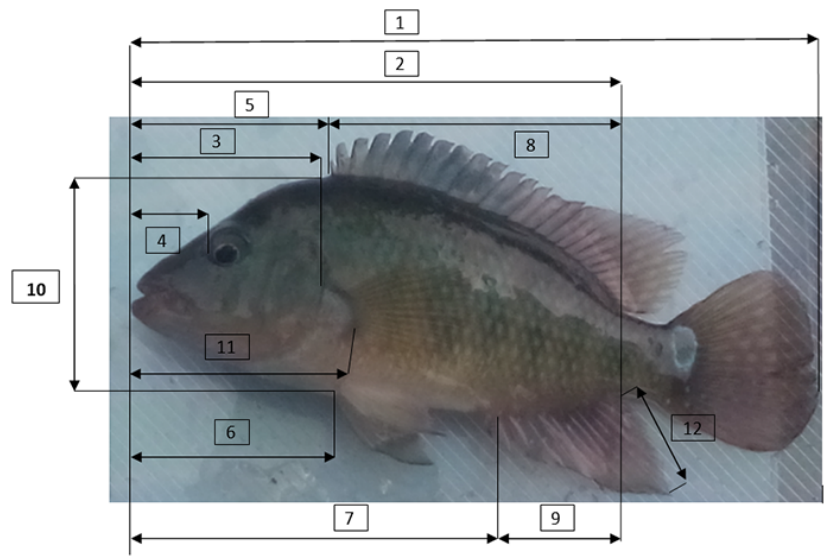

Figure 1. The morphometric measurements registered in each analysed organism (source: own elaboration). 1: total length (TL); 2 : standard length (SL); 3: head length (HL); 4: pre-orbital length (PreOL); 5: pre-dorsal length (Pre-DL); 6: pre-ventral length (Pre-VL); 7: pre-anal length (Pre-AL); 8: dorsal fin length (DFL); 9: pharyngeal bone length (PhBL); 10: maximum height body $(\mathrm{MaxBH}) ; 11$ : pectoral fin length (PFL); 12: anal fin length (AFL).

\subsection{Body measurements}

Lineal morphometric measurements were taken on the left side of fish, by the same person in order to minimize artificial error, and most of the morphometric characters were measured following the conventional method described by Morales et al. (1998) and Diodatti et al. (2008). The fish were measured using a measuring board, measuring tape and digital callipers graduated in millimetres and then weighed with an electronic weighing balance up to the nearest $0.1 \mathrm{~g}$ (Figs. 1 and 2). Meristic characteristics were examined according to Froese and Pauly (2007). A total of 26 body measurements were used, including 21 morphometric variables and 4 meristic variables (Table 1 ).

\subsection{Fulton condition factor $(K)$}

The Fulton condition factor $(K)$, which is defined as the well-being of the fish, was calculated. $K$ is a useful index for monitoring of feeding intensity, age and growth rates. The $K$ was calculated with the following equation: $K=$ $(100 \times \mathrm{BW}) / \mathrm{SL}^{3}$, where BW refers to body weight of fish in grams and SL is the standard length of fish in centimetres.

\subsection{Length-weight relationship}

Length-weight relationships were calculated using the allometric regression analysis (Sasi and Berber, 2012). Lengthweight was expressed as $\mathrm{BW}=a \times \mathrm{SL}^{b}$, the logarithm transformation of which gives the linear equation $\log \mathrm{BW}=a+$ $(b \times \log \mathrm{SL})$, where BW refers to body weight of fish in grams, SL is the standard length of fish in centimetres, $a$ is the constant for the initial growth index and $b$ is the growth

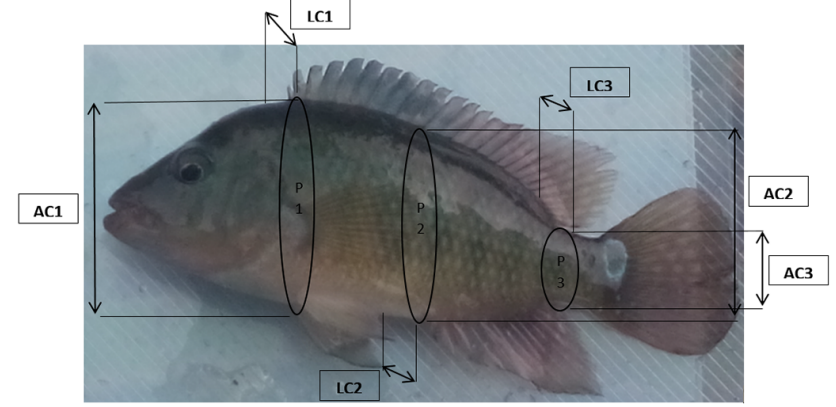

Figure 2. The morphometric measurements registered in each analysed organism (source: own elaboration). AC1: body depth at the first ray of the dorsal fin; AC2: body depth at the level of the first ray of the anal fin; AC3: body depth at the level of the first radius of the caudal fin; P1: body perimeter of the body at the level of the first ray of the dorsal fin; P2: body perimeter at the level of the first radius of the anal fin; P3: body perimeter at the level of the last ray of the dorsal fin; LC1: head width; LC2: trunk width; LC3: tail width.

coefficient. Constants $a$ and $b$ represent the point at which the regression line intercepts the $y$ axis and the slope of the regression line, respectively.

\subsection{Statistical analyses}

All statistical analyses were performed using SAS University Edition 3.5 (SAS Institute, Cary, NC). Each collection site was considered a priori as a discrete group. To evaluate whether the data have equal variances, a Bartlett test was done prior to further analyses. Means, standard deviation (SD) and coefficient of variation $(\mathrm{CV} \%)$ were recorded for each population.

The morphometric (continuous) and meristic (discrete) data were analysed separately. Since meristic characters are independent of size and did not change during growth $(\mathrm{Tu}-$ ran et al., 2006), the raw data were used in analysis. However, to avoid possible biases produced by size effects on the morphometric variables, all morphometric characters were standardized by the following equation (Elliott et al., 1995): $M_{\text {adj }}=M\left(L_{\mathrm{s}} / L_{\mathrm{o}}\right)^{b}$, where $M$ is the original morphometric measurement, $M_{\mathrm{adj}}$ the size adjusted measurement, $L_{\mathrm{o}}$ the standard length of fish and $L_{\mathrm{S}}$ the overall mean of standard length for all fish from all samples for each variable. The parameter $b$ was estimated for each character from the observed data as the slope of the regression of $\log M$ on $\log L_{0}$, using all specimens. This method normalizes the individuals in a sample to a single, arbitrary size, common to all samples and, at the same time, maintains the individual variation (Tudela, 1999). It has been successfully used by many researchers in recent years (Ibañez-Aguirre and Lleonart, 1996; Salini et al., 2004; Turan et al., 2006). The efficiency of the size-adjustment transformations was assessed by testing the significance of the correlation between a transformed variable and the SL. 
Table 1. Body measurements.

\begin{tabular}{|c|c|c|}
\hline Trait & & Description \\
\hline \multicolumn{3}{|l|}{ Morphometric variables } \\
\hline Body weight & BW & Measured as total weight including gut and gonads \\
\hline Total length & $\mathrm{TL}$ & Measured from the middle of the upper lip of the mouth to the caudal end of the caudal fin \\
\hline Standard length & SL & $\begin{array}{l}\text { Measured between the central portion of the upper lip of the mouth and the base of the caudal } \\
\text { fin }\end{array}$ \\
\hline Head length & HL & $\begin{array}{l}\text { Distance between the most cranial point of the upper lip of the mouth and the rear end of the } \\
\text { operculum }\end{array}$ \\
\hline Pre-orbital length & Pre-OL & $\begin{array}{l}\text { Distance between the most cranial point of the lower lip of the mouth and the cranial edge of } \\
\text { the eye }\end{array}$ \\
\hline Pre-dorsal length & Pre-DL & Distance between the most cranial point of the lower lip and the start of the first dorsal spine \\
\hline Pre-ventral length & Pre-VL & $\begin{array}{l}\text { Distance between the most cranial point of the lower lip and the start of the first spine of the } \\
\text { ventral fin }\end{array}$ \\
\hline Pre-anal length & Pre-AL & Distance between the most cranial point of the lower lip and the beginning of the anal orifice \\
\hline Dorsal fin length & DFL & Distance from the most cranial point of the base of the fin to the caudal end of the dorsal fin \\
\hline Pharyngeal bone length & PhBL & Distance from the most cranial point of the base of the fin to the caudal end of the anal fin \\
\hline Maximum height body & $\mathrm{MaxBH}$ & Distance between the most cranial point of the pectoral fin and the lateral line \\
\hline Pectoral fin length & PFL & Distance between the base point cranial flap to the rear end of greater radii \\
\hline Anal fin length & AFL & Distance from the most cranial point of the base of the fin to the end of anal fin \\
\hline Body depth & $\mathrm{AC} 1$ & Measured with a calliper, at the first ray of the dorsal fin \\
\hline Body depth & $\mathrm{AC} 2$ & Measured with a ruler, at the level of the first ray of the anal fin \\
\hline Body depth & $\mathrm{AC} 3$ & Measured with a calliper, at the level of the first radius of the caudal fin \\
\hline Head width & $\mathrm{LC} 1$ & Distance from side to side at the level of the flow side of the head \\
\hline Trunk width & $\mathrm{LC} 2$ & Distance from side to side at the level of the most cranial point of the anal fin side \\
\hline Tail width & LC3 & Distance from side to side at the level of the last thorn on the back side \\
\hline Body perimeter & $\mathrm{P} 1$ & Measured with measuring tape, at the level of the first ray of the dorsal fin \\
\hline Body perimeter & $\mathrm{P} 2$ & Measured with measuring tape, at the level of the first radius of the anal fin \\
\hline Body perimeter & $\mathrm{P} 3$ & Measured with measuring tape, at the level of the last ray of the dorsal fin \\
\hline \multicolumn{3}{|l|}{ Meristic variables } \\
\hline Dorsal fin rays & DFR & Count of thorns has the dorsal fin from start to finish \\
\hline Radius dorsal fin & $\mathrm{RDF}$ & Count of cartilage found in the space between thorns from start to finish \\
\hline Anal fin rays & AFR & Count of thorns has the anal fin from start to finish \\
\hline Radius anal fin & RAF & Count of cartilage found in the space between thorns from start to finish \\
\hline
\end{tabular}

Size-adjusted morphometric data and meristic characters were compared by univariate analysis of variance (ANOVA procedure) and Kruskal-Wallis test (NPAR1WAY procedure), respectively, using the group (cultured or wild) as the fixed effect. In addition, the DISCRIM procedure was used to perform a canonical discriminant analysis of both sizeadjusted morphometric data and meristic characters. The variables that would be included as predictors in the canonical discriminant function were previously selected with the STEPDISC procedure. The probabilities to enter and to stay in the model were both set at 0.05 .

\section{Results}

\subsection{Morphometric characters}

Morphometric and meristic traits mean values of Cichlasoma festae from cultured and wild specimens are shown in Table 2 .

Among the morphometric characters, the most used are the body weight (BW), total length (TL), standard length (SL) and head length (HL). The mean BW of Cichlasoma festae from all data ranged from 55.8 to $152.0 \mathrm{~g}$ with a mean value of $90.45 \pm 18.2 \mathrm{~g}$. The value of TL ranged between 12.5 and $25.0 \mathrm{~cm}$ with a mean value of $18.27 \pm 1.75 \mathrm{~cm}$, SL ranged between 9.8 and $19.0 \mathrm{~cm}$ with a mean value of $14.14 \pm 1.58 \mathrm{~cm}$, and HL ranged between 4.4 and $6.5 \mathrm{~cm}$ with a mean value of $5.35 \pm 0.48 \mathrm{~cm}$. Cultured fish were larger than those coming from a natural habitat, so weight and most morphometric variables showed higher mean values, except for LC3. The mean Pre-OL, AFL, LC2, LC3, AFR and RAF of Cichla- 
Table 2. Descriptive statistics of the morphometric and meristic characters (original data) from Cichlasoma festae.

\begin{tabular}{|c|c|c|c|c|c|c|c|}
\hline & \multicolumn{3}{|c|}{ All data } & \multicolumn{2}{|c|}{ Cultured } & \multicolumn{2}{|c|}{ Wild } \\
\hline & Mean & SD & $\mathrm{CV} \%$ & Mean & $\mathrm{CV} \%$ & Mean & $\mathrm{CV} \%$ \\
\hline Body weight (g) & 90.45 & 18.16 & 20.07 & $101.84^{\mathrm{a}}$ & 16.43 & $79.06^{\mathrm{b}}$ & 13.94 \\
\hline Fulton condition factor, $K$ & 3.32 & 0.92 & 27.80 & $3.01^{\mathrm{a}}$ & 22.41 & $3.62^{\mathrm{b}}$ & 28.65 \\
\hline Total length $(\mathrm{cm})$ & 18.27 & 1.75 & 9.60 & $19.40^{\mathrm{a}}$ & 7.17 & $17.14^{\mathrm{b}}$ & 7.54 \\
\hline Standard length $(\mathrm{cm})$ & 14.14 & 1.58 & 11.18 & $15.12^{\mathrm{a}}$ & 8.00 & $13.15^{\mathrm{b}}$ & 9.64 \\
\hline Head length $(\mathrm{cm})$ & 5.35 & 0.48 & 9.03 & $5.57^{\mathrm{a}}$ & 8.52 & $5.14^{\mathrm{b}}$ & 7.66 \\
\hline Pre-orbital length $(\mathrm{cm})$ & 2.18 & 0.44 & 20.07 & $2.27^{\mathrm{a}}$ & 23.43 & $2.10^{\mathrm{a}}$ & 14.40 \\
\hline Pre-dorsal length (cm) & 5.37 & 0.67 & 12.44 & $5.69^{\mathrm{a}}$ & 7.81 & $5.05^{\mathrm{b}}$ & 13.93 \\
\hline Pre-ventral length (cm) & 5.83 & 0.57 & 9.71 & $6.20^{\mathrm{a}}$ & 7.94 & $5.45^{\mathrm{b}}$ & 6.11 \\
\hline Pre-anal length $(\mathrm{cm})$ & 9.05 & 0.92 & 10.22 & $9.28^{\mathrm{a}}$ & 11.98 & $8.83^{\mathrm{b}}$ & 7.08 \\
\hline Pectoral fin length(cm) & 8.01 & 0.88 & 10.96 & $8.25^{\mathrm{a}}$ & 9.91 & $7.78^{\mathrm{b}}$ & 11.32 \\
\hline Pharyngeal bone length $(\mathrm{cm})$ & 3.40 & 0.43 & 12.67 & $3.52^{\mathrm{a}}$ & 12.10 & $3.27^{\mathrm{b}}$ & 12.25 \\
\hline Maximum body height (cm) & 3.90 & 0.60 & 15.26 & $4.16^{\mathrm{a}}$ & 12.91 & $3.64^{\mathrm{b}}$ & 14.82 \\
\hline Dorsal fin length (cm) & 5.99 & 0.69 & 11.52 & $6.40^{\mathrm{a}}$ & 10.41 & $5.58^{\mathrm{b}}$ & 7.53 \\
\hline Anal fin length $(\mathrm{cm})$ & 4.58 & 1.02 & 22.27 & $4.78^{\mathrm{a}}$ & 22.15 & $4.39^{\mathrm{a}}$ & 21.66 \\
\hline $\mathrm{AC} 1(\mathrm{~cm})$ & 5.46 & 0.45 & 8.24 & $5.75^{\mathrm{a}}$ & 7.04 & $5.16^{\mathrm{b}}$ & 4.85 \\
\hline $\mathrm{AC} 2(\mathrm{~cm})$ & 4.93 & 0.40 & 8.22 & $5.18^{\mathrm{a}}$ & 6.53 & $4.67^{\mathrm{b}}$ & 6.27 \\
\hline $\mathrm{AC} 3(\mathrm{~cm})$ & 1.94 & 0.25 & 12.86 & $2.03^{\mathrm{a}}$ & 9.73 & $1.84^{\mathrm{b}}$ & 14.05 \\
\hline $\mathrm{LC} 1(\mathrm{~cm})$ & 2.31 & 0.27 & 11.77 & $2.41^{\mathrm{a}}$ & 8.79 & $2.21^{\mathrm{b}}$ & 13.06 \\
\hline $\mathrm{LC} 2(\mathrm{~cm})$ & 1.56 & 0.36 & 23.03 & $1.57^{\mathrm{a}}$ & 27.45 & $1.55^{\mathrm{a}}$ & 17.73 \\
\hline $\mathrm{LC} 3(\mathrm{~cm})$ & 0.71 & 0.23 & 32.72 & $0.69^{\mathrm{a}}$ & 24.43 & $0.74^{\mathrm{a}}$ & 38.49 \\
\hline $\mathrm{P} 1(\mathrm{~cm})$ & 13.24 & 1.00 & 7.55 & $13.72^{\mathrm{a}}$ & 8.11 & $12.76^{\mathrm{b}}$ & 4.43 \\
\hline $\mathrm{P} 2(\mathrm{~cm})$ & 11.36 & 0.68 & 6.01 & $11.78^{\mathrm{a}}$ & 5.01 & $10.95^{\mathrm{b}}$ & 4.51 \\
\hline P3 (cm) & 4.73 & 0.44 & 9.41 & $4.87^{\mathrm{a}}$ & 9.63 & $4.58^{\mathrm{b}}$ & 8.11 \\
\hline Dorsal fin rays & 27.04 & 0.98 & 3.64 & $27.32^{\mathrm{a}}$ & 3.09 & $26.76^{\mathrm{b}}$ & 3.89 \\
\hline Radius dorsal fin & 26.12 & 1.54 & 5.89 & $26.52^{\mathrm{a}}$ & 7.07 & $25.72^{\mathrm{b}}$ & 3.77 \\
\hline Anal fin rays & 13.70 & 0.76 & 5.54 & $13.80^{\mathrm{a}}$ & 5.86 & $13.60^{\mathrm{a}}$ & 5.15 \\
\hline Radius anal fin & 12.82 & 0.85 & 6.59 & $12.80^{\mathrm{a}}$ & 6.31 & $12.84^{\mathrm{a}}$ & 6.92 \\
\hline
\end{tabular}

$\mathrm{AC} 1$ : body depth at the first ray of the dorsal fin; AC2: body depth at the level of the first ray of the anal fin; AC3: body depth at the level of the first radius of the caudal fin; LC1: head width between the right and left point at the level of the flow side of the head; LC2: trunk width between the right and left at the level of the most cranial point of the anal fin side; LC3: tail width between the right and left at the level of the last thorn on the back side; P1: body perimeter of the body at the level of the first ray of the dorsal fin; P2: body perimeter at the level of the first radius of the anal fin; P3: body perimeter at the level of the last ray of the dorsal fin.

$\mathrm{a}, \mathrm{b}$ Within a row, means without a common superscript are different $(p<0.05)$.

soma festae from the two populations were not significantly different from each other.

The TL, HL, Pre-VL, AC1, AC2, P1, P2 and P3 showed a coefficient of variation lower than $10 \%$; SL, Pre-DL and Pre-AL, PFL, PhBL, MaxBH, DFL, AC3 and LC1 showed a coefficient of variation between 10 and $20 \%$; and the BW, Pre-OL, AFL, LC2 and LC3 showed coefficients of variation greater than $20 \%$. The coefficients of variation of different morphometric characters were not significantly $(p<0.05)$ different between populations, except for Pre-OL, Pre-DL, Pre-AL, AC3, LC2 and LC3.

The meristic characters showed mean values of $27.04 \pm 1.0, \quad 26.12 \pm 1.5, \quad 13.70 \pm 0.8$ and $12.82 \pm 0.9$ for DFR, RDF, AFR and RAF, respectively, with no significant difference $(p<0.05)$ among populations. The coefficients of variation were very low $(<7 \%)$ and similar between populations.

Dorsal fin rays (DFR) and radius dorsal fin (RDF) ranged from 24 to 28, with most in the range of 27-28 (82\%) and 26-27 $(70 \%)$, respectively. In anal fin rays (AFR) and radius dorsal fin (RDF) ranged from 11 to 15 , presenting most of the 13-14 (82\%) and 12-13 (76\%) respectively. Significant differences $(p<0.05)$ between cultured and wild were found (data not shown). The range of the dorsal fin characters was higher for wild (W) than cultured (C) fishes, although $27(56 \%$ for $\mathrm{C}$ and $36 \%$ for $\mathrm{W})$ and $26(48 \%$ for $\mathrm{C}$ and $18 \%$ for $\mathrm{W}$ ) were the most frequent classes for DFR and $\mathrm{RDF}$, respectively. Conversely, the range for anal fin characters (AFR and RAF) was higher for C (12-15 and 11-14) than $\mathrm{W}$ (13-15 and 12-14), and the most frequent class dif- 
fered between populations $(14=44 \%$ for $\mathrm{C}$ and $13=52 \%$ for $\mathrm{W}$, and $13=52 \%$ for $\mathrm{C}$ and $12=44 \%$ for $\mathrm{W}$ ).

The mean BW/SL ratio was 6.39 \pm 0.98 . HL SL, MaxBH , body depth (AC1, AC2, AC3), body width (LC1, LC2, LC3) and body perimeter $(\mathrm{P} 1, \mathrm{P} 2, \mathrm{P} 3)$ represented $38 \%, 28 \%, 39$ to $14 \%, 16$ to $5 \%$ and 94 to $34 \%$, respectively. The ratios of TL, Pre-VL, Pre-VL, DFL, AC1, AC2, P1 and P2 with SL showed a coefficient of variation lower than $10 \%$; ratios BW, HL, Pre-DL, Pre-AL, PFL, PhBL, MaxBH, AC3, LC1 and $\mathrm{P} 3$ with SL showed a coefficient of variation between 10 and $20 \%$, while ratios of Pre-OL, AFL, LC2 and LC3 showed coefficients of variation greater than $20 \%$. In general, the coefficients of variation of the indices are slightly lower than those recorded in the corresponding morphological measurements.

Among populations, the BW / SL was significantly higher $(p<0.05)$ in the cultured population, while the ratios of HL / SL, Pre-AL / SL, PFL / SL, PhBL / SL, AC1 / SL, AC2 / SL, LC1 / SL, LC2 / SL, LC3 / SL, P1 / SL, P2 / SL and P3 / SL were significantly higher $(p<0.05)$ in the wild population. Based on these relationships, wild fish were proportionately more profound at the cranial level than cultured, without significant differences $(p>0.05)$ at the caudal level. Likewise, at the cranial and caudal levels, they were proportionally wider. All of this caused the body perimeter / SL ratios, both at cranial and caudal levels significantly, to be lower $(p<0.05)$ in cultured fish.

After standardizing according to Elliot et al. (1995), the mean values of BW, TL, SL and HL were $90.38 \pm 1.87$, $18.32 \pm 0.13,14.14 \pm 0.16$ and $5.36 \pm 0.06 \mathrm{~cm}$, respectively. The habitat had a significant effect $(p<0.05)$ in some of the morphometric characters evaluated. BW, TL, SL, HL, PreVL, DFL, AC1, AC2, AC3 and P2 were significantly higher $(p<0.05)$ in cultured specimens. AFL, LC1 and P1 tended to be higher $(p<0.1)$ in the cultured population.

\subsection{Fulton condition factor}

The mean value of the condition factor $K$ was $3.32 \pm 0.9$ (Table 2) for the original data set, with mean values of 3.01 and 3.62 for cultured and wild populations, respectively. The coefficient of variation was high $(27.8 \%)$. Once the data were adjusted to SL (Elliot et al., 1995), the mean value of the condition factor $K$ was $3.47 \pm 0.15$, with significantly higher values $(p<0.001)$ in the wild than in the cultured population, where the values were $4.07 \pm 0.24$ and $2.86 \pm 0.12$, respectively.

\subsection{Length-weight relationship}

The parameter $b$ of the fish studied ranged from a minimum of 1.57 to a maximum of 2.46, with a mean value of $2.096 \pm 0.078$, and with a slightly higher average value in cultured fish when compared with wild fish (2.21 vs. 1.97).
Table 3. Fisher's discriminant functions for morphometric variables.

\begin{tabular}{lrr}
\hline & Cultured & Wild \\
\hline Constant & -441.77 & -375.03 \\
SL & 19.77 & 17.80 \\
Pre-VL & 41.88 & 38.83 \\
AC2 & 57.95 & 54.36 \\
AFL & 8.19 & 7.47 \\
\hline
\end{tabular}

SL: standard length; Pre-VL: pre-ventral length; AC2: body depth at the level of the first ray of the anal fin; AFL: anal fin length.

\subsection{Relationships between morphometric characters}

The morphometric relationships between numerous body parts of fish can be used to determine possible difference between separate unit stocks of the same species (King, 2007). Several significant $(p<0.05)$ positive correlations were found between the morphometric and meristic characters of the two populations (data not shown). Most correlation coefficients were between 0.3 and 0.5 . The results reveal that the size effect was almost entirely eliminated in the populations during analysis as there were no significant correlations between TL and SL, with most of the remaining parameters measured with the analysed characters. Meristic characters, except for RDF, are not significantly related $(p>0.05)$ to each other or other morphometric characters.

\subsection{Discriminant analysis}

Four morphometric variables (SL, Pre-VL, AC2, AF1) out of 23 were selected as predictors in the canonical discriminant analysis (Table 3$)$. Wilks' lambda $(0.39 ; p<0.001)$ indicated that the data were appropriate for discriminant analysis, whereas the eigenvalue (1.54) and canonical correlation (0.78) showed that the canonical function had very good discrimination ability.

The Mahalanobis squared distance between the cultured and wild populations was 6.03 , and the $F$ test of the distance was highly significant $(p<0.001)$. SL, followed at some distance by Pre-VL, AC2 and AFL, had the greatest discriminating ability and the highest correlation value with the canonical discriminant function, according to the standardized canonical coefficients and the pooled within-canonical structure, respectively. Fisher's linear discriminant functions are shown in Table 2. In the original classification matrices, eight cases were misclassified in the cultured group and four cases were misclassified in the wild group. In cross-validated classification matrices, nine cases were misclassified in the cultured group and seven cases were misclassified in the wild group. As a result, 88 and $84 \%$ of the original grouped cases were classified correctly in the original and cross-validated classification matrices, respectively. 
Regarding meristic variables, the only RDF was selected as predictor and, despite the Wilks' lambda statistical significance $(p<0.01)$, the eigenvalue and the canonical correlation were very low ( 0.09 and 0.29 , respectively). The obtained Fisher's linear discriminant functions correctly classified 61 and $58 \%$ of the original grouped cases in the original and cross-validated classification matrices, respectively.

\section{Discussion}

\subsection{Morphometric characters}

According to Turan et al. (2006), the introduction and domestication of a fish species (especially those from the wild) leads to high adaptation to a wide range of geographical locations, which leads to phenotypic variations with respect to the pure stock (strains) of the brood stock. In order to know the ecological variation and to evaluate morphological differences between wild and cultured fish of the same species, different authors have used morphometric and meristic variables (Narváez et al., 2005; Fagbuaro et al., 2015; Solomon et al., 2015) to quantify biological variation and identify and explain adaptive processes of different populations of the same species.

On the basis of the classification of Negi and Nautiyal (2002), of the morphological characters studies from Barilius bendelisis and Barilius vagra, 12 characters were genetically controlled, 8 characters were intermediate and 7 characters were environmentally controlled. Twenty-one characters have been studied in percentage of standard fish length, from which seven characters were genetically controlled, nine characters were intermediate and five characters were environmentally controlled.

In the current study, it has been observed that the meristic counts did not change with increasing or decreasing body weight and length of the fish. Similar variations in meristic characters were reported in many fishes such as Nematalosa nasus (Al-Hassan, 1987), Pseudobagrus ichikawai (Watanabe, 1998), Pterophyllum scalare (Bibi-Koshy et al., 2008), Garra gotyla gotyla (Gray) (Brraich and Akhter, 2015).

This study recorded significant differences $(p<0.05)$ between populations in 11 morphometric parameters, in agreement with Fagbuaro et al. (2005) and Solomon et al. (2015). Barriga-Sosa et al. (2004), after analysing morphometric characters in natural and domesticated populations of Nile tilapia (Oreochromis niloticus), reported morphological differences among these populations. Likewise, Narváez et al. (2005) found significant differences between the two populations (wild and cultured) of Oreochromis niloticus in northern Colombia; differences were attributed to food, environmental conditions and the type of habitat (wild and cultured). However, in the present study, not all meristic characters registered showed significant differences between populations, in contrast to the results obtained by Solomon et al. (2005) in Clarias gariepinus. The discrepancy between results could be attributed to the characters studied in each work.

In the present study, TL / SL and DFL / SL ratios were not significantly $(p>0.05)$ different between cultured and wild specimens, in contrast to results obtained by El-Zaeem et al. (2012). While there is overlap between the two works in the differences between populations (cultured and wild) in the ratio between the standard length and depth and width of the body. These authors point out that the highest mean value of TL / SL in Nile tilapia (Oreochromis niloticus) was recorded by cultured population and differed significantly $(P<0.05)$ from that of the wild population. Also, the mean value of $\mathrm{HL} / \mathrm{AC1}$ ratio was not significantly different between populations (wild and cultured), in contrast to the results offered by Narváez et al. (2005), who observed that domesticated individuals were characterized by sharper heads than those of naturalized fish. Solomon et al. (2015) recorded significant differences in the ratio HL / SL in wild (23.7) and cultured (26.6) populations of $C$. gariepinus. Similarly, Vreven et al. (1998) and Barriga-Sosa et al. (2004) indicated that the biggest differences between wild and cultured populations were presented at the head. The value of this relationship and other relationships between morphometric characters is closely linked to the species, so it is not surprising that differences can be registered between studies. Thus, Van der Bank et al. (1989) reported mean values from 0.29 to 0.34 for HL / SL and 0.31 to 0.45 for body depth/SL in fifteen cichlid fish species endemic to southern Africa, whereas in our study means the values for these ratios were 0.38 and 0.39 , respectively. Brraich and Akter (2015) in Garra gotyla gotyla (Gray) recorded mean values of 0.27 and 0.18 , respectively. According Vreven et al. (1998) the confinement of domesticated fish affects their growth rate, without allowing elongate the body, which would result in a higher $K$ value. Contrary to this, in our work the value of $K$ is higher in wild specimens.

\subsection{Fulton condition factor $(K)$}

Condition factor is a useful index for the monitoring of feeding intensity, age and growth rates in fish (Oni et al., 1983). It is strongly influenced by both biotic and abiotic environmental conditions and can be used as an index to assess the status of the aquatic ecosystem in which fish live.

The condition factor values of Cichlasoma festae from the current study (3.32) were comparable to those registered by Chukwuemeka et al. (2014) in Tilapia aurea, Tilapia galilaea and Auchenoglanis occidentalis and lower than those reported by Anene (2005) in four cichlid fish (4.9). However, Fagbuaro et al. (2015) recorded significantly lower values (0.68) in Clarias gariepinus fish. The correlation coefficients between the factor $K$ and the total length or standard length are negative $(-0.488$ and -0.774 for cultured fish and -0.557 and -0.873 for wild fish, respectively) and statistically significant $(p<0.01$ and 0.001$)$, indicating that a shortened factor occurs with increasing size of the fish. These re- 
sults are consistent with those obtained in four cichlid species by Anene (2005), who registered a significant and progressive decrease $(p<0.05)$ between the size range of 120 and $150 \mathrm{~mm}$. Sasi and Berber (2012) recorded increases in condition factor until the age of 5 years (from 1.6 to 2.5 ) and a drop below.

In disagreement with Fagbuaro et al. (2015), the condition factor $K$ was higher in the wild population. This implies that the fish from the cultured population may not have been fed to the required level.

\subsection{Length-weight relationship}

In the present study, the length-weight relationship parameter $b$ is lower than in many studies (Abdallah, 2002; Bayhan et al., 2008; Sasi and Berber, 2012) and close (2.27-2.46) to that obtained by Fagbuaro et al. (2015), although it is located in the range of values (1.51-3.49) indicated by Bok et al. (2011). This study shows that the fish from both the cultured and wild fish population have exhibited no isometric relative growth, which does not maintain their specific body shape throughout their life. These results also showed that both wild and cultured habitats do not provide enough food to maintain an isometric growth.

In contrast to the results obtained by Fagbuaro et al. (2015) (2.27 for farmed fish and 2.46 for wild fish), in the present study the parameter $b$ was higher in the cultured population.

\subsection{Correlation among morphometric variables}

Out of 26 characters, 2 characters show high values of correlation coefficient and 24 characters show moderate to low correlation coefficient. In Cichlasoma festae, BW was found to be the most correlated part. In general, the correlation coefficients between morphological variables were slightly higher among wild fish, and clearly lower than those recorded by Brraich and Akhter (2015) in Garra gotyla gotyla. Chukwuemeka et al. (2014) recorded correlation coefficients between live weight and standard length of 0.76 to 0.94 in Tilapia galilaea, Tilapia aurea and Auchenoglanis occidentalis from Tagwai Lake (Nigeria). The variations observed in correlation coefficients of the morphometric and meristic data for wild and cultured Cichlasoma festae, aligned with the results obtained by Solomon et al. (2015), could be strongly linked to feeding pattern, environmental conditions and genetic variability. Also, there is sufficient evidence to prove the influence of habitat on fish morphology (Turan et al., 2006).

\subsection{Discriminant analysis}

Canonical discriminant analysis demonstrated a clear influence of origin in the morphometric variables and a low effect in the meristic characters measured in the present work. The fact that only four morphometric variables were needed to separate the two groups suggests that Fisher's linear discriminant could be useful to identify the origin of stocks on a commercial basis. However, Van der Bank et al. (1989) attribute less value to the morphologic variables than to meristic counts in the differentiation of populations of the same species. The meristic counts showed a very low variability and overlapped broadly, showing no divergence among the populations, in agreement with several authors (Gacitúa et al., 2008; El-Zaeem et al., 2012; Solomon et al., 2015). These characters, due to their relative stability, cannot give the necessary variability in measurements which is essential for multivariate analysis and stock discrimination studies.

Although the causes of morphological differences between populations are often quite difficult to explain, the morphometric differences between the cultured and wild Cichlasoma festae could have been linked to environmental factors; furthermore, breeding over several years may have diluted the initial gene pool of the domesticated fish, leading to genetic variation (translating to morphological differences) (Solomon et al., 2015).

\section{Conclusions}

Our results show that the rearing system significantly influences most of the analysed morphometric and meristic characteristics of the two populations (wild and cultured) of $\mathrm{Ci}$ chlasoma festae. Twenty-two morphometric and four meristic characters were used to test the hypothesis differentiation. Univariate analysis of variance showed significant differences for 21 standardized morphometric measurements out of 26 characters among the means of the wild and cultured populations tested. The condition factor values were significantly different from each other and showed that feeding could be improved in the farms. Both groups were accurately separated by linear discriminant functions that included only four morphometric measures. These results are of vital importance for the Ecuadorian population because they will allow for planning of further breeding and conservation strategies for this native fish and improving productivity.

\section{Data availability}

The original data are available upon request to the corresponding author.

Edited by: M. Mielenz

Reviewed by: J. Rivas and one anonymous referee 


\section{References}

Abdallah, M.: Length-weight relationship of fishes caught by trawl off Alexandria, Egypt, Naga-The ICLARM Quarterly, 25, 19-20, 2012.

Ajah, P. O., Georgewill, M. N., and Ajay, M. O.: The food and feeding habits of five fresh water and brackish water fish species in Nigeria, Afr. J. Aquat. Sci., 31, 313-318, 2006.

Al-Hassan, L. A. J.: Variations in meristic characters of Nematalosa nasus from Iraqi and Kuwaiti waters, Jpn. J. Ichthyol., 33, 422425, 1987.

Anene, A.: Condition Factor of Four Cichlid Species of a Man-made Lake in Imo State, Southeastern Nigeria, Turk. J. Fish. Aquat. Sc., 5, 43-47, 2005.

Barnhill, B., Lopez, E., and Les, A.: Estudio sobre biología de los peces del río Vinces, Instituto Nacional de Pesca, Boletín Científico Técnico, Vol. III, 1974.

Barriga-Sosa, I. D., Jiménez-Badillo, M. D. Ibáñez, A. L., and Arredondo-Figueroa, J. L.: Variability of tilapias (Oreochromis spp.) introduced in Mexico: morphometric, meristic and genetic characters, J. Appl. Ichthyol., 20, 7-14, 2004.

Bayhan, B., Sever, T., and Taskavak, E.: Age, length-weight and diet composition of Scaldfish Arnoglossus laterna (Walbaum, 1792) (Pisces: Bothidae) in Izmit Bay (Aegean Sea), J. Anim. Vet. Adv., 7, 924-929, 2008.

Bibi-Koshy, E., Oyyan, S., and Sekaran, M.: Variation in meristic characters of four strains of Malaysian freshwater angelfish, Pterophyllum scalare (L.), Malaysian J. Sci., 27, 69-73, 2008.

Bok, T. D., Gokturk, D., Kahraman, A. E., Alicli, T. Z., Acun, T., and Ates, C.: Length-Weight relationship of 34 fish species from the Sea of Marmara, J. Anim. Vet. Adv., 10, 3037-3042, 2011.

Boulenger, G. A.: Poissons de l'Équateur. Deuxième Partie, Bollettino dei Musei di Zoologia ed Anatomia Comparata della R. Università di Torino, 14, 1-8, 1899.

Brraich, O. S. and Akhter, S.: Morphometric Characters and Meristic Counts of a Fish, Garra gotyla gotyla (Gray) from Ranjit Sagar Wetland, situated in the Himalayan foothills, India, Int. J. Biol. Sci, 4, 66-72, 2015.

Cabral, H. N., Marques, J. F., Rego, A. L., Catarino, A. I., Figueiredo, J., and Garcia, J.: Genetic and morphological variation of Synaptura lusitanica Capello, 1868, along the Portuguese coast, J. Sea Res., 50, 167-175, 2003.

Chávez-Lomelí, M. O., Mattheeuws, A. E., and Pérez-Vega, M. H.: Biología de los peces del río San Pedro en vista de determinar su potencial para la piscicultura, Instituto Nacional de Investigaciones sobre Recursos Bióticos, Villahermosa, Tabasco, 222 pp., 1988.

Chukwuemeka, V. I., Tsadu, S. M., Ayanwale, V. A., Erhabor, O. F., and Falusi, F. M.: Morphometric of Selected Fish Species from Tagwai Lake, Minna, Niger State, Nigeria, Adv. Agric. Biol., 2, 140-143, 2014.

Diodatti, F. C., Fonseca de Freitas, R. T., Freato, T. A., Pérez Ribeiro, P. A., and Solis Murgas, L. D.: Parámetros morfométricos en el rendimiento de los componentes corporales de tilapia del Nilo (Oreochromis Niloticus), Anales de Veterinaria de Murcia, 24, 45-55, 2008.

Elliott, N. G., Haskard, K., and Koslow, J. A.: Morphometric analysis of orange roughy (Hoplostethus atlanticus) off the continental slope of southern Australia, J. Fish Biol., 46, 202-220, 1995.
El-Zaeem, S. Y., Ahmed, M., El-Sayed-Salama, M. M., and Abd ElKader, W. N.: Hhylogenetic differentiation of wild and cultured Nile tilapia (Oreochromis niloticus) populations based on phenotype and genotype analysis, Afr. J. Agric. Res., 7, 2946-2954, 2012.

Espinosa-Lemus, V., Arredondo-Figueroa, J. L., and Barriga-Sosa, L. A.: Morphometric and generic characterization of Tilapia (Cichlidae) stock for effective fisheries management in two Mexican reservoirs, Hidrobiológica, 19, 95-107, 2009.

Fagbuaro, O., Oso, J. A., Olurotimi, M. B., and Akinyemi, O.: Morphometric and Meristic Characteristics of Clarias gariepinus from Controlled and Uncontrolled Population from Southwestern Nigeria, J. Agric. Ecol. Res. Int., 2, 39-45, 2015.

FAO: El consumo de pescado y fauna acuática silvestre en la amazonía ecuatoriana, Roma, available at: http://www.fao.org/ docrep/014/ba0024s/ba0024s.pdf (last access: 15 April 2016), 2011.

Froese, R. and Pauly, D.: Fish base 2007, World Wide Web electronic publication, available at: http://www.fishbase.org (last access 17 March 2016), 2007.

Frost, W. E. and Kipling, C.: The growth of char, Salvelinus willughbii Gunther in Windermere, J. Fish Biol., 16, 279-90, 1980.

Gacitúa, S., Oyarzún, C., and Veas, R.: Análisis multivariado de la morfometría y merística del robalo Eleginops maclovinus $(\mathrm{Cu}-$ vier, 1830), Rev. Biol. Mar. Oceanog., 43, 491-500, 2008.

Hossain, M. A. R., Nahiduzzaman, M., Saha, D., Khanam, M. U. H., and Alam, M. S.: Landmark-Based morphometric and meristic variations of the endangered carp, Kalibaus Labeo calbasu, from stocks of two isolated Rivers, the Jamuna and Halda and a Hatchery, Zool. Stud., 49, 556-563, 2010.

Ibañez-Aguirre, A. L. and Lleonart, J.: Relative growth and comparative morphometrics of Mugil cephalus L. and M. curema V. in the Gulf of Mexico, Sci. Mar., 60, 361-368, 1996.

Johal, M. S., Tandon, K. K., and Sandhu, G. S.: Mahseer in Lacustrine Waters, Gobindsagar Reservoir, in: Morphometry of Tor putitora, Mahseer the Game Fish, Jagdamba, edited by: Nautiyal, P., Prakashan Publisher, Srinagar, Garhwal, 67-85, 1994.

King, M.: Fisheries biology, assessment and management, 2nd Edn., Blackwell Scientific Publications, Oxford, 1-381, 2007.

Konings, A.: Cichlids from Central America, Tfh Pubns Inc., Neptune City, New Jersey, 222 pp., 1989.

Luna-Figueroa, J. and Figueroa, T. J.: Reproducción y crecimiento en cautiverio de la mojarra criolla Cichlasoma istlanum (Pisces : Cichlidae), AquaTIC, 10, 1-13, 2000-

Muñoz, P. O., Alvarez, F., and Capa, C. P.: El conocimiento ancestral sobre la pesca, en las comunidades shuar asentadas en el corredor fluvial Zamora - Nangaritza, CEDAMAZ, 112-127, 2014.

Morales, R., Arenal, A. Q., Pimentel, R., Mendoza, I., Cruz, A., Martínez, R., Herrera, F., Tápanes, L., Estrada, M. P., and de la Fuente, J.: Caracterización del fondo genético de la línea de supertilapias IG/03-F70, I. Caracteres morfométricos, merísticos y análisis de ADN, Biotecnol. Appl., 15, 15-21, 1998.

Narváez, B., Acero, A., and Blanco, J.: Variación morfométrica en poblaciones naturalizadas y domesticadas de la tilapia del Nilo Oreochromis niloticus (Teleostei : Cichlidae) en el norte de Colombia, Revista de la Academia Colombiana de Ciencias, 29, 383-394, 2005. 
Negi, R. S. and Nautiyal, P.: Analysis of growth pattern and variation in some morphometric characters of sympatric hill stream Teleosts, Barilius bendelisis and Barilius vagra, Asian Fish. Sci., 15, 335-346, 2002.

Oni, S. K., Olayemi, J. Y., and Adegboye, J. D.: Comparative physiology of three ecologically distinct fresh water fishes, Alestes nurse Ruppell, Synodontis schall Bloch and S. Schneider and Tilapia zilli Gervais, J. Fish Biol., 22, 105-109, 1983.

Orban, E., Nevigato, T., Di Lena, G., Casini, I., and Marzetti, A.: Differentiation in the lipid quality of wild and farmed seabass (Dicentrarchus labrax) and Gilthead Sea bream (Sparus aurata), J. Food Sci., 68, 128-132, 2003.

Pacheco, L. and Chicaiza, D.: Estudio en el Embalse Chongon, Instituto Nacional de Pesca, available at: http://www.inp.gov.ec, 2008.

Pinheiro A, Teixeira, C. M., Rego, A. L., Marques, J., and Cabral, H.: Genetic and Morphological variation of solealascarIs (Risso, 1810) along the Portuguese coast, Fish. Res., 73, 67-78, 2005.

Ponton D. and Mérigoux, S.: Comparative morphology and diet of young cichlids in the dammed Sinnamary river, French Guiana, South America, J. Fish Biol., 56, 87-102, 2000.

Revelo, W. and Elias, E.: Aspectos biológicos de los principales recursos de aguas continentales, durante Febrero y Marzo del 2004 en la provincia de los Ríos, Instituto Nacional de Pesca, 21 pp., 2004.

Salini, J., Milton, D., Rahman, M., and Hussain, M.: Allozyme and morphological variation throughout the geographic range of the tropical shad, hilsa Tenualosa ilisha, Fish. Res., 66, 53-69, 2004.

Sasi, H. and Berber, S.: Age, growth and some biological characteristics of white bream (Blicca bjoerk na L., 1758) in Uluabat lake, in Northwestern of Anatolia, Asian J. Anim. Vet. Adv., 7, 262-267, 2012.

Solem, O., Berg, O. K., and Kjosnes, A. J.: Inter and intrapopulation morphological differences between wild and farmed Atlantic salmon juveniles, J. Fish Biol., 69, 1466-1481, 2006.
Solomon, S. O., Okomoda, V. T., and Ogbenyikwu, A. I.: Intraspecific morphological variation between cultured and wild Clarias gariepinus (Burchell) (Clariidae, Siluriformes), Arch. Pol. Fish, 23, 53-61, 2015.

Swain, D. P. and Foote, C. J.: Stocks and chameleons the use of phenotypic variation in stock identification, Fish. Res., 43, 113128, 1999.

Swain, D. P., Ridell, B. E., and Murray, C. B.: Morphological differences between hatchery and wild populations of coho salmon (Oncorhynchus kisutch): environmental versus genetic origin, Can. J. Fish Aquat. Sci., 48, 1783-1791, 1991.

Tudela, S.: Morphological variability in a Mediterranean, genetically homogeneous population of the European anchovy, Engraulis encrasicolus, Fish. Res., 42, 229-243, 1999.

Turan, C., Oral, M., Öztürk, B., and Düzgüneş, E.: Morphometric and meristic variation between stocks of Bluefish (Pomatomus saltatrix) in the Black, Marmara, Aegean and northeastern Mediterranean Seas, Fish. Res., 79, 139-147, 2006.

Van der Bank, F. H., Ferreira, J. T., and Grant, W. S.: An evaluation of morphometric and meristic characters frequently used in identification keys for fifteen cichlid fish species endemic to southern Africa, Madoqua, 16, 77-85, 1989.

Vreven, E. J., Adèpo-Gourène, B., Agnèse, J. F., and Teugels, G. G.: Morphometric and allozyme in populations and cultured strains of the Nile tilapia Oreochromis niloticus (Teleostei, Cichlidae), Belg. J. Zool., 128, 23-34, 1998.

Watanabe, K.: Meristic variation in the endangered bagrid catfish, Pseudobagrus ichikawai, Ichthyol. Res., 45, 99-104, 1998.

Wimberger, P. H.: Plasticity of fish body shape the effects of diet, development, family and age in two species of Geophagus (Pisces, Cichlidae), Biol. J. Linnean Soc., 45, 197-218, 1992. 